\title{
Genotype 1 of human parvovirus B19 in clinical cases
}

Maria Isabel de Oliveira ${ }^{1 *}$, Ana Maria Sardinha Afonso ${ }^{2}$, Suely Pires Curti ${ }^{1}$, Patrícia Evelin Silva ${ }^{2}$, Tamyris Fernanda Barbosa ${ }^{2}$, Elian Reis Silva Junior ${ }^{2}$, Cristina Adelaide Figueiredo ${ }^{1}$

${ }^{1}$ PhD, Scientific Researcher, Núcleo de Doenças Respiratórias, Instituto Adolfo Lutz, São Paulo, SP, Brazil

${ }^{2}$ MSc Student, Núcleo de Doenças Respiratórias, Instituto Adolfo Lutz, São Paulo, SP, Brazil

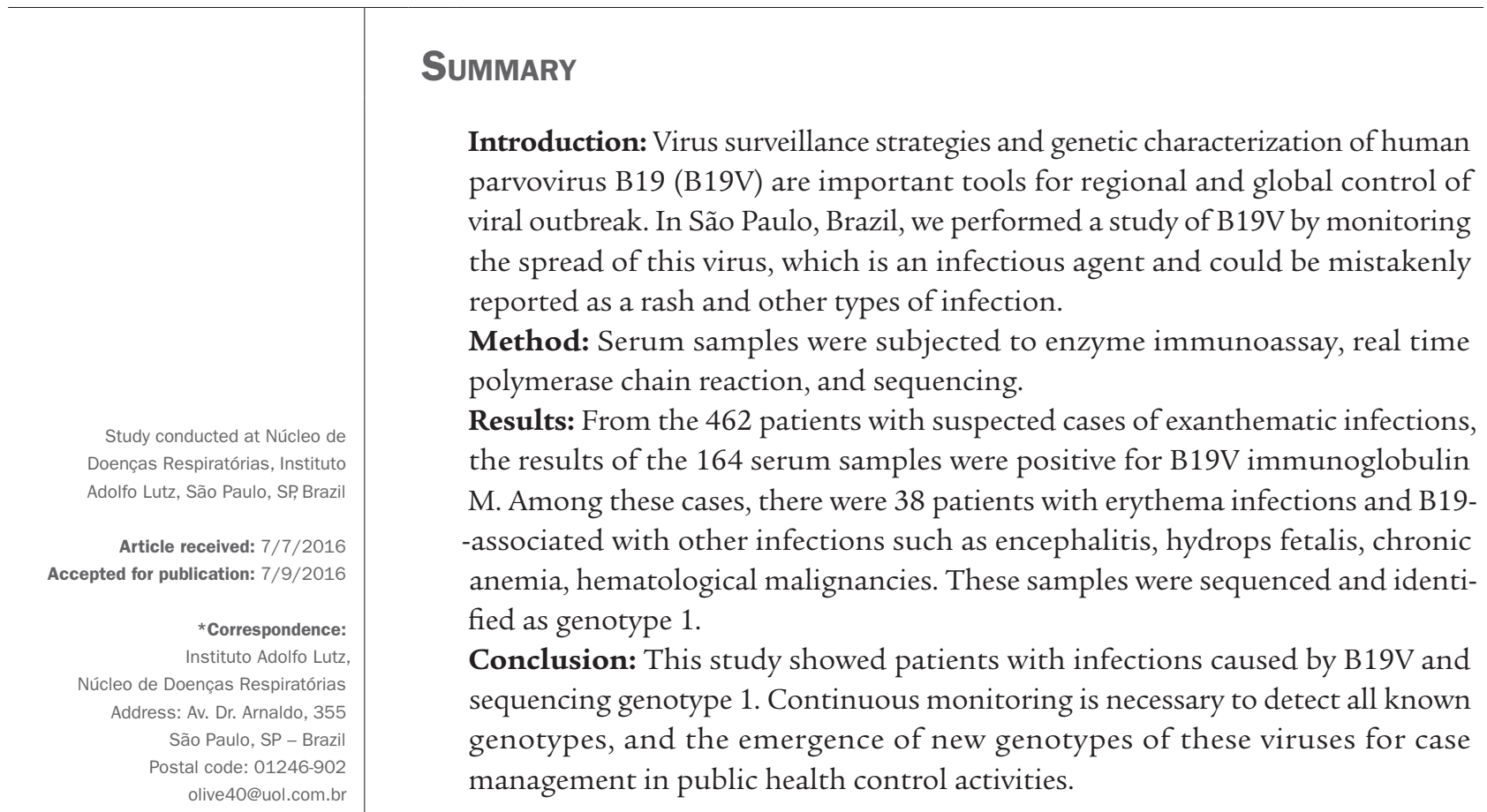

Keywords: human parvovirus B19, B19V genotype, surveillance.

\section{INTRODUCTION}

Human parvovirus B19 (B19V) is a member of the Parvoviridae family. It is further classified into the subfamily Parvovirinae, genus Erythrovirus, and species Parvovirus B19. B19V causes erythema infectiosum, a clinical form most commonly seen in children and adolescents, although it may occur at any age in pregnant women, causing serious or even fatal complications to the fetus. Damage in the erythroid progenitor cells caused by B19V can result in severe anemia, particularly in immunocompromised patients. In addition, B19V infection has been associated with many clinical symptoms, such as neurological and myocardial infections, among others. ${ }^{1-3} \mathrm{~B} 19 \mathrm{~V}$ infection is often associated with fever and rash, and many times can be mistakenly reported as measles, rubella or other very common exanthema infections. ${ }^{4}$

Based on the phylogenetic analysis of the B19V, it was proposed into three distinct genotypes: $1 ; 2$; and 3 groups. To determine which genotypes of B19V are present in São
Paulo city, clinical samples were analyzed, and carried out the genetic characterization of the circulating strains causing exanthematic diseases. That are important tools for regional and global control of viral outbreak.

\section{Method}

This study was conducted between 2009 and 2012 at Adolfo Lutz Institute, São Paulo, Brazil, with surveillance specimens collected from 462 patients with suspected $\mathrm{B} 19 \mathrm{~V}$. The ages of the patients ranged from 1 month to 55 years of age. Blood samples were collected from individuals with erythema infectiosum, and B19-associated conditions such as encephalitis, hydrops fetalis, severe and chronic anemia, hematological malignancies, and aplastic anemia. Samples were tested using the B19V immunoassay kit and specific immunoglobulin $\mathrm{M}$ and $\mathrm{G}$ for identification of the VP2 protein (Biotrin International Ltd., Dublin, Ireland). The same samples were processed by real time qPCR (quantitative polymerase chain reaction) 
and probes were designed to sequence the fragment region of the NS1-VP1 gene, encoding for the B19V non-structural protein (position 1399 to 1659), as previously described by Takano \& Yamada, ${ }^{6}$ using QIAamp ${ }^{\circledR}$ DNA Blood Mini Kit (Qiagen, Hilden, Germany). The samples were sequenced by nested-PCR using primers described by Servants. ${ }^{5}$ The amplified products were purified with PureLink PCR Purification Kit (Invitrogen/Life Technologies, Carlsbad, CA) and sequenced using the ABI Prism Big Dye Terminator v3.1 Cycle Sequencing Kits (Applied Biosystems, Foster City, CA) according to the manufacturer's protocol. The sequences obtained were analyzed by CLUSTAL X and BioEdit version 7.0 phylogenetic analysis applications. The sequence generated from the erythrovirus HPV B19 sample was submitted to Blast searches in the GenBank accession numbers, sample from, locations, isolation years, and genotype of the sequences utilized as presented in Table 1. Alignment was used with prototype sequences of genotype 1: strain Pvbua (Acc.Number M13178), genotype 2: prototype strain Lali (Acc. Number AY044266), and genotype 3: prototype strain V9 (Acc. Number AY647977) by the Clustal X program (http://www-igbmc.u-strasbg.fr/BioInfo/ClustalX/) and analyzed by the Megalign, DNAstar, Inc. software.

\section{RESULTS}

In order to detect the presence of B19V, an immunoassay of the 462 suspected cases of exanthematic infections was done: 164 (36\%) serum samples were positive for B19V IgM and 298 (64\%) were positive for B19V IgG. Of the 498 samples analyzed by qPCR, 148 (32\%) were found to be positive for $\mathrm{B} 19 \mathrm{~V}$ protein expression. The infection was equally distributed between male and female patients under the age of 20.

Among the positive samples, 38 with erythema infection and B19-associated were sequenced. The results of the immunoassay (IgG and IgM antibodies) showed 21 samples were positive for both $\operatorname{IgM} / \operatorname{IgG}$ antibodies, six were negatives IgM/IgG antibodies, seven were positive for IgG antibodies only, and one was positive for IgM only (Table 1). Among the three samples collected from the cerebrospinal fluid (CSF), one was positive while the remaining two were negative for both $\operatorname{IgM} / \operatorname{IgG}$ antibodies. The 15 samples clinically negative for IgM and/or IgG antibodies, but positive for the same according to DNA analysis, were collected from patients within 3-5 days after the onset of symptoms. In total, 38 sequences were obtained (eight from samples collected in 2009, 18 from 2010, eight from 2011, and four from 2012). All 38 sequences belonged to genotype1 of B19V (Figure 1). A comparison of the nucleotide sequences of the different strains showed a high level of identity. Nucleotide pairwise identity among the different strains ranged from 97 to $99.1 \%$ in genotype $1,86.8$ to $88 \%$ in genotype 2 , and 87.2 to $88.5 \%$ in genotype 3 . The sequences within genotype 1 were found to be similar (statistical deviation within group, $1.7 \%$ ).

\section{Discussion}

In our study, we observed that $36 \%$ of the serum samples were positive for B19V IgM and 64\% were positive for B19V IgG. In the article described by Candotti et al., the percentage of positivity for IgG and IgM was similar to our findings. Clinical symptoms of B19 infection in $39.8 \%$ of the patients exhibiting B19-specific IgM were found in patients from Rio de Janeiro and the same results were obtained. ${ }^{8}$

$\mathrm{B} 19 \mathrm{~V}$ infection causes a benign disease, and neurological complications have been seen but are not usually investigated in encephalitis. ${ }^{3}$ Among the cases where the genotype was analyzed, three cases of encephalitis were observed. This was particularly evident in a young man, from whose B19V from CSF was amplified and showed genotype 1.

The incidence of acute $\mathrm{B} 19 \mathrm{~V}$ infection in pregnancy is approximately $1-2 \%$ during the endemic period. However, during the time of an epidemic, the infection rate may rise to $>10 \%{ }^{9}$ The peak incidence of $\mathrm{B} 19 \mathrm{~V}$-associated hydrops fetalis is between 17 and 24 weeks of gestation..$^{10,11}$ Testing maternal serum for IgM/IgG antibodies against parvovirus B19, and DNA detection by PCR can confirm maternal infection. Among the total number of samples analyzed in our study, three were diagnosed with hydrops fetalis, and all three were positive for infection by parvovirus $\mathrm{B} 19$. The rapid correction of anemia by in uterus transfusion of packed erythrocytes largely prevents fetal death. Among the cases analyzed, the majority were associated with hematological disorders. Patients with hemoglobinopathies can be vulnerable to $\mathrm{B} 19 \mathrm{~V}$ persistence due to shortened red blood cell survival..$^{12}$ These persistent infections have been reported to be associated with chronic anemia, thrombocytopenia and pancytopenia, arthralgia, or arthritis. ${ }^{13}$ Our results showed high positivity for B19V infection from IgM/G assay and qPCR, in patients with hematological malignancy (Table1).

Our findings are consistent with the results reported by other groups. Studies have reported high positivity for B19V IgG in hematological malignancy cases, aplastic anemia, and chronic hematological disorders. ${ }^{14,15}$ These results are relevant when clinical symptoms are first observed in conditions with a more prolonged evolution of disease with no specific etiological diagnosis and where the disease may be identified by the presence of IgG. 
TABLE 1 Characteristics of B19V subjected to genetical analyses.

\begin{tabular}{|c|c|c|c|c|c|c|c|c|c|c|}
\hline \multirow{2}{*}{$\begin{array}{l}\text { Case } \\
\text { no. }\end{array}$} & \multirow[t]{2}{*}{ GeneBank } & \multirow[t]{2}{*}{ Symptoms } & \multirow{2}{*}{$\begin{array}{l}\text { Month/ } \\
\text { Year }\end{array}$} & \multirow{2}{*}{$\begin{array}{l}\text { Specimen } \\
\text { collection }\end{array}$} & \multirow{2}{*}{$\begin{array}{l}\text { Age (days/ } \\
\text { years) }\end{array}$} & \multirow[t]{2}{*}{ Sex } & \multicolumn{2}{|c|}{ Serology } & \multirow[t]{2}{*}{ RT-PCR } & \multirow[t]{2}{*}{ Group } \\
\hline & & & & & & & IgG & $\operatorname{Ig} M$ & & \\
\hline 1 & JX 559664 & Hydrops fetalis & $01 / 2009$ & Sera & 1 & M & Pos & Neg & Pos & 1 \\
\hline 2 & JX 559665 & Erythema infectiosum & $02 / 2009$ & Sera & 14 & $\mathrm{~F}$ & Pos & Pos & Pos & 1 \\
\hline 3 & JX 559661 & Transient anemia & $08 / 2009$ & Sera & 14 & M & Pos & Pos & Pos & 1 \\
\hline 4 & JX 559660 & Aplastic anemia & 09/2009 & Sera & 28 & $\mathrm{~F}$ & $\mathrm{Neg}$ & $\mathrm{Neg}$ & Pos & 1 \\
\hline 5 & JX 559656 & Severe anemia & $10 / 2009$ & Sera & 23 & $\mathrm{~F}$ & Pos & Pos & Pos & 1 \\
\hline 6 & JX 559654 & Hydrops fetalis & $12 / 2009$ & Sera & $7 \mathrm{D}$ & $\mathrm{F}$ & Pos & Pos & Pos & 1 \\
\hline 7 & JX 559658 & Transient anemia & $12 / 2009$ & Sera & 2 & M & Neg & Neg & Pos & 1 \\
\hline 8 & JX 559652 & Chronic anemia & $12 / 2009$ & Sera & 40 & $\mathrm{~F}$ & $\mathrm{Neg}$ & $\mathrm{Neg}$ & Pos & 1 \\
\hline 9 & JX 559673 & Severe anemia & $01 / 2010$ & Sera & 34 & $\mathrm{~F}$ & $\mathrm{Neg}$ & $\mathrm{Neg}$ & Pos & 1 \\
\hline 10 & JX 559663 & Encephalitis & $01 / 2010$ & CSF & 47 & M & Pos & Pos & Pos & 1 \\
\hline 11 & JX 559655 & Aplastic anemia & $01 / 2010$ & Sera & 20 & M & Pos & Pos & Pos & 1 \\
\hline 12 & JX 559653 & Erythema infectiosum & $01 / 2010$ & Sera & 25 & $\mathrm{~F}$ & Pos & Pos & Pos & 1 \\
\hline 13 & JX 559659 & Hydrops fetalis & $01 / 2010$ & Sera & $3 \mathrm{D}$ & M & Pos & Pos & Pos & 1 \\
\hline 14 & JX 465351 & Erythema infectiosum & $01 / 2010$ & Sera & 20 & M & Pos & Pos & Pos & 1 \\
\hline 15 & JX 559657 & Encephalitis & $02 / 2010$ & CSF & 26 & $\mathrm{~F}$ & $\mathrm{Neg}$ & Neg & Pos & 1 \\
\hline 16 & JX 267259 & Encephalitis & $03 / 2010$ & CSF & 2 & M & $\mathrm{Neg}$ & $\mathrm{Neg}$ & Pos & 1 \\
\hline 17 & JX 559662 & Erythema infectiosum & $04 / 2010$ & Sera & 45 & $\mathrm{~F}$ & Neg & Neg & Pos & 1 \\
\hline 18 & JX 267261 & Severe anemia & $05 / 2010$ & Sera & 55 & M & Pos & Neg & Pos & 1 \\
\hline 19 & JX 559650 & Severe anemia & $05 / 2010$ & Sera & 7 & M & Pos & Neg & Pos & 1 \\
\hline 20 & JX 559651 & Chronic anemia & $06 / 2010$ & Sera & 30 & $\mathrm{~F}$ & Pos & $\mathrm{Neg}$ & Pos & 1 \\
\hline 21 & $J \times 267260$ & Chronic anemia & $06 / 2010$ & Sera & 19 & M & Pos & Pos & Pos & 1 \\
\hline 22 & JX 267257 & Aplastic anemia & $06 / 2010$ & Sera & 19 & M & Pos & Neg & Pos & 1 \\
\hline 23 & JX 559674 & Severe anemia & $08 / 2010$ & Sera & 2 & $\mathrm{~F}$ & Pos & Neg & Pos & 1 \\
\hline 24 & JX 559648 & $\begin{array}{l}\text { Hematological } \\
\text { malignancies }\end{array}$ & $08 / 2010$ & Sera & 20 & M & Pos & Pos & Pos & 1 \\
\hline 25 & JX 559649 & Severe anemia & $08 / 2010$ & Sera & 4 & $\mathrm{~F}$ & Pos & Pos & Pos & 1 \\
\hline 26 & $J \times 267258$ & Erythema infectiosum & $09 / 2010$ & Sera & 1 & M & Pos & Neg & Pos & 1 \\
\hline 27 & $J \times 267252$ & Erythema infectiosum & $04 / 2011$ & Sera & 18 & M & Pos & Pos & Pos & 1 \\
\hline 28 & $J \times 267254$ & Transient anemia & $04 / 2011$ & Sera & 6 & $\mathrm{~F}$ & $\mathrm{Neg}$ & Neg & Pos & 1 \\
\hline 29 & JX 267256 & Erythema infectiosum & $07 / 2011$ & Sera & 8 & M & Pos & Pos & Pos & 1 \\
\hline 30 & JX 267255 & Severe anemia & $07 / 2011$ & Sera & 8 & M & Pos & Pos & Pos & 1 \\
\hline 31 & $J \times 267253$ & Severe anemia & $07 / 2011$ & Sera & 9 & $\mathrm{~F}$ & Pos & Pos & Pos & 1 \\
\hline 32 & JX 559670 & Erythema infectiosum & $09 / 2011$ & Sera & 5 & M & Pos & Pos & Pos & 1 \\
\hline 33 & JX 559669 & Severe anemia & $10 / 2011$ & Sera & 5 & $\mathrm{~F}$ & $\mathrm{Neg}$ & Pos & Pos & 1 \\
\hline 34 & JX 559668 & Severe anemia & $11 / 2011$ & Sera & 9 & $\mathrm{~F}$ & Pos & Pos & Pos & 1 \\
\hline 35 & JX 559667 & Erythema infectiosum & $01 / 2012$ & Sera & 12 & M & Pos & Pos & Pos & 1 \\
\hline 36 & JX 559666 & Erythema infectiosum & $01 / 2012$ & Sera & 5 & $\mathrm{~F}$ & Pos & Pos & Pos & 1 \\
\hline 37 & JX 559671 & Chronic anemia & $01 / 2012$ & Sera & 50 & $\mathrm{~F}$ & Pos & Pos & Pos & 1 \\
\hline 38 & JX 559672 & Severe anemia & $03 / 2012$ & Sera & 21 & $\mathrm{~F}$ & Pos & Pos & Pos & 1 \\
\hline
\end{tabular}

CSF: cerebrospinal fluid; Pos: positive; Neg: negative; RT-PCR: reverse transcription-polymerase chain reaction. 


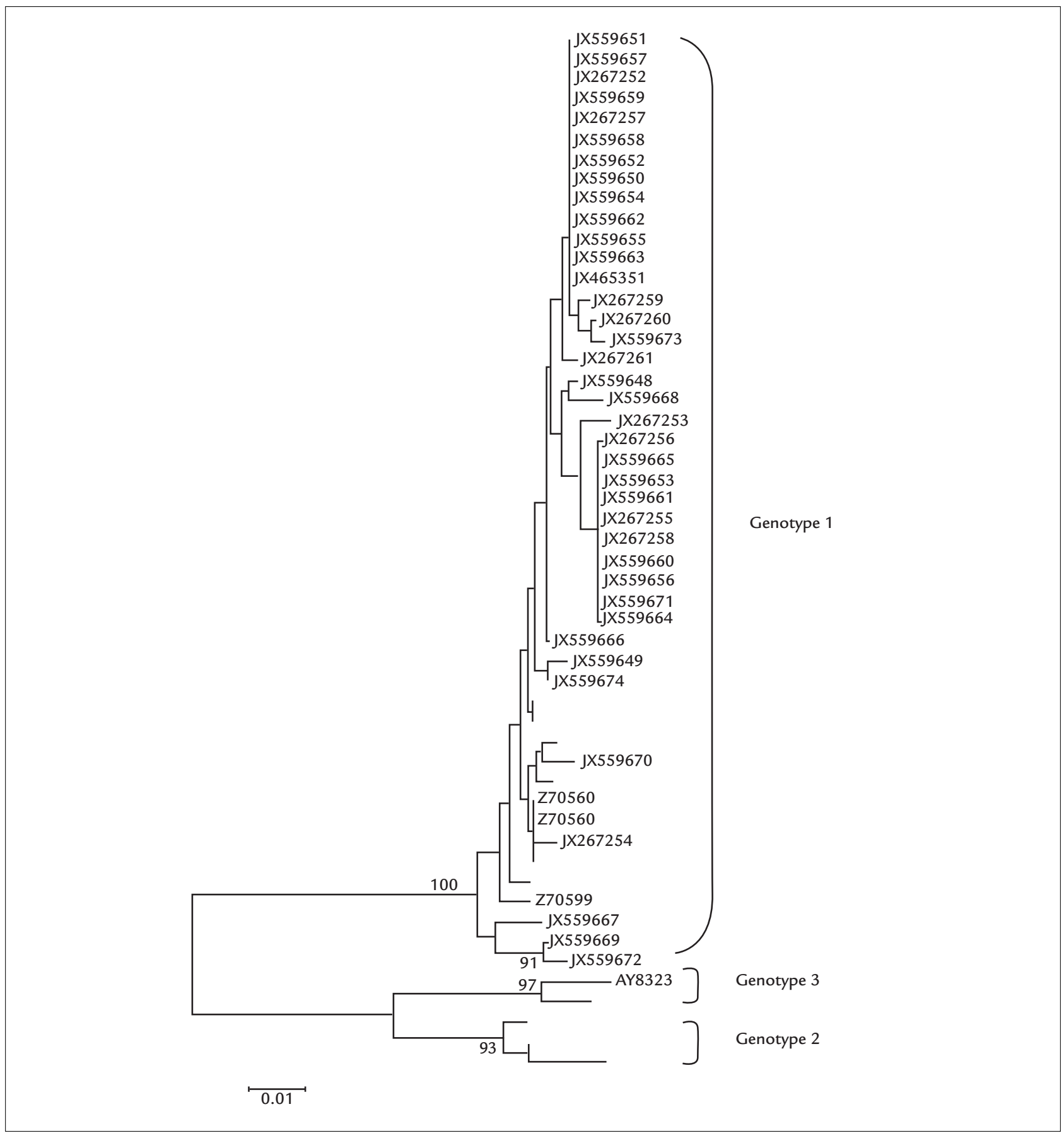

FIGURE 1 Phylogenetic relationships of the nucleotide sequences of B19V strains circulating São Paulo, Brazil, 2009-2012. The tree constructed with the NJ method was evaluated by the bootstrap method with 1,000 replications using MEGA package version 4.0.1.

Currently, there are three B19V genotypes with associated subtypes, genotype $1 \mathrm{a}, 1 \mathrm{~b}, 2,3 \mathrm{a}$, and $3 \mathrm{~b} .{ }^{16}$ The genotypes show $\sim 10 \%$ nucleotide divergence on the whole genome. ${ }^{5}$ The most prevalent B19V genotype in Northern Europe is genotype 1a. Genotype 2 appears to be restricted to people born before 1970, and genotype 3 predominantly occurs in people from West Africa, France and
Brazil. ${ }^{17}$ Some studies have shown that B19V genetic diversity may depend on the geographical location and the year of isolation in patients. In this study, all isolates belonged to genotype $1 .{ }^{17}$ In Brazil, all three genotypes have been identified, although genotype 1 is the most common. ${ }^{14}$ Genotype 1 has also been isolated in Vietnam, with a higher frequency of occurrence in children and adults. ${ }^{18}$ 
In addition, genotype 1 is predominant in the Midwest, South and Southeast regions of Brazil. ${ }^{19,20}$

This work shows the presence of B19V genotype 1 . Continuous monitoring is necessary to detect all known genotypes, and the emergence of new genotypes related to infection as the cause of virus spread.

\section{Conflict of interest}

The authors declare no conflict of interest.

\section{Resumo}

Genótipo 1 do parvovírus humano em casos clínicos

Introdução: Estratégias de vigilância para o parvovírus humano B19 e caracterização genética são ferramentas importantes para o controle regional e global do surto viral. Em São Paulo, Brasil, foi realizado um estudo de parvovírus B19, monitorando a disseminação desse vírus, que é um agente infeccioso e poderia ser erroneamente relatado como uma erupção cutânea e outros tipos de infecções.

Método: As amostras de soro foram submetidas ao ensaio imunoenzimático, PCR quantitativo em tempo real e sequenciamento.

Resultados: Dos 462 pacientes com casos suspeitos de infecções exantemáticas, os resultados das 164 amostras de soro foram positivos para parvovírus B19 imunoglobulina M. Entre eles, 38 pacientes com eritema infeccioso apresentaram B19 associado com outras infecções, como encefalite, hidropisia fetal, anemia crônica, doenças hematológicas malignas. Essas amostras foram sequenciadas e identificadas como genótipo 1 .

Conclusão: Os pacientes foram infectados com parvovírus B19 e apresentaram genótipo 1. Monitoração contínua é necessária para detectar todos os genótipos conhecidos e o surgimento de novos genótipos para o controle de casos em saúde pública.

Palavras-chave: parvovírus humano B19, genótipo $\mathrm{B} 19 \mathrm{~V}$, vigilância.

\section{RefEREnCES}

1. Figueiredo CA, Oliveira MI, Afonso AMS, Andrade JQ, Brizot ML, Zugaib $\mathrm{M}$, et al. Detection of human parvovirus B19 in cases of hydrops fetalis in São Paulo, Brazil. J Bras Patol Med Lab. 2008; 44(6):423-7.

2. Young NS, Brown KE. Parvovirus B19. N Engl J Med. 2004; 350(6):586-97.

3. Watanabe T, Kawashima H. Acute encephalitis and encephalopathy associated with human parvovirus B19 infection in children. World J Clin Pediatr. 2015; 4(4):126-34.

4. Rezaei F, Sarshari B, Ghavami N, Meysami P, Shadad A, Salimi H, et al. Prevalence and genotype characterization of Human Parvovirus B19 in children with measles- and rubella-like illness in Iran. J Med Virol. 2016; 88(6):947-53.

5. Servant A, Laperche S, Lallemand F, Marinho V, De Saint Maur G, Meritet JF, et al. Genetic diversity within human erythroviruses: identification of three genotypes. J Virol. 2002; 76(18):9124-34.

6. Takano T, Yamada K. Quantification of human parvovirus B19 DNA by real-time polymerase chain reaction. Pediatr Int. 2007; 49(4):459-62.

7. Candotti D, Etiz N, Parsyan A, Allain JP. Identification and characterization of persistent human erythrovirus infection in blood donor samples. J Virol. 2004; 78(22):12169-78.

8. Wermelinger MC, Oelemann WM, Lima de Mendonça MC, Naveca FG von Hubinger MG . Detection of human parvovirus B19 infection: a study of 212 suspected cases in the state o Rio de Janeiro, Brazil. J Clin Virol. 2002; 25(2):223-30.

9. de Jong EP, de Haan TR, Kroes ACM, Beersma MFC, Oepkes D, Walther FJ Parvovirus B19 infection in pregnancy. J Clin Virol. 2006; 36(1):1-7.

10. Dijkmans AC, de Jong EP, Dijkmans BA, Lopriore E, Vossen A, Walther FJ, et al. Parvovirus B19 in pregnancy: prenatal diagnosis and management of fetal complications. Curr Opin Obstet Gynecol. 2012; 24(2):95-101.

11. Adam O, Makkawi T, Reber U, Kirberg H, Eis-Hübinger AM. The seroprevalence of parvovirus B19 infection in pregnant women in Sudan. Epidemiol Infect. 2015; 143(2):242-8.

12. Slavov SN, Kashima S, Silva-Pinto AC, Covas DT. Genotyping of Human parvovirus B19 among Brazilian patients with hemoglobinopathies. Can J Microbiol. 2012; 58(2):200-5.

13. Modrow S, Dorsch S. Antibody responses in parvovirus B19 infected patients. Pathol Biol (Paris). 2002; 50(5):326-31.

14. Rogo LD, Mokhtari-Azad T, Kabir MH, Rezaei F. Human parvovirus B19: a review. Acta Virol. 2014; 58(3):199-213.

15. Ishikawa A, Yoto $\mathrm{Y}$, Tsugawa $\mathrm{T}$, Tsutsumi H. Quantitation of human parvovirus B19 DNA in erythema infectiosum and aplastic crisis. J Med Virol. 2014; 86(12):2102-6.

16. Enders M, Weidner A, Zoellner I, Searle K, Enders G. Fetal morbidity and mortality after acute human parvovirus B19 infection in pregnancy: prospective evaluation of 1018 cases. Prenat Diagn. 2004; 24(7):513-8.

17. Servant-Delmas A, Lefrère JJ, Morinet F, Pillet S. Advances in human B19 erythrovirus biology. J Virol. 2010; 84(19):9658-65.

18. Toan NL, Duechting A, Kremsner PG, Song le H, Ebinger M, Aberle S, et al Phylogenetic analysis of human parvovirus B19, indicating two subgroups of genotype 1 in Vietnamese patients. J Gen Virol. 2006; 87(Pt 10):2941-9.

19. Mendonça MC, Ferreira AM, Santos MG, Oviedo EC, Bello MS, Siqueira MM, et al. Genotyping of human parvovirus B19 in clinical samples from Brazil and Paraguay using heteroduplex mobility assay, single-stranded conformation polymorphism and nucleotide sequencing. Mem Inst Oswaldo Cruz. 2011; 106(4):502-4

20. Conteville LC, Zanella L, Marín MA, Filippis AM, Nogueira RM, Vicente AC, et al. Parvovirus B19 1A complete genome from a fatal case in Brazil. Mem Inst Oswaldo Cruz. 2015; 110(6):820-1. 